\title{
The Impact of Content-based Instruction on Students' Achievement in ESP Courses and Their Language Learning Orientation
}

\author{
Mostafa Amiri \\ English Department, Ferdowsi University of Mashhad (the International Campus), Mashhad, Iran \\ Azar Hosseini Fatemi \\ English Department, Ferdowsi University of Mashhad, Mashhad, Iran
}

\begin{abstract}
This paper investigated the effect of Content-based Instruction (CBI) on students' English language learning. In so doing, two methods of teaching English, that is, the CBI and the Grammar Translation Method (GTM) were compared with regard to the students' achievement in their final examination and language learning orientation. The subjects consisted of 82 freshmen who were randomly assigned into two groups at Gonabad University of Medical Sciences. To collect data, three instruments were employed: the Nelson test of achievement form $050 \mathrm{C}$, the Language Learning Orientation Scale (LLOS) questionnaire, and a final achievement test. The data were analyzed using t-test and some correlational analyses. The results indicated that there was no significant difference between the groups regarding the Nelson test and LLOS at the onset of the study, but there was a significant difference between the groups' performance regarding the method of teaching English. In other words, the group taught through the CBI outperformed the one taught through the GTM ( $p=0.006$ and $p<0.05$ for the GTM and CBI groups, respectively). Moreover, there was a significant difference in the subjects' language learning orientation after treatment $(p=0.038)$. Some suggestions and implications were put forward for the EFL/ESL teachers to consider.
\end{abstract}

Index Terms - Content-based Instruction (CBI), Grammar-Translation Method (GTM), achievement, Nelson test, Language Learning Orientation Scale (LLOS)

\section{INTRODUCTION}

The history of language teaching and learning has seen different developments through which various methods and approaches have emerged. The Grammar Translation method was dominant in Europe and some other countries for teaching foreign languages from the 1840s to the 1940s. Next, due to the advances in the areas of psychology and linguistics, language teaching enjoyed a scientific importance and the Audiolingual method emerged. Then, other alternative approaches and methods such as Total Physical Response, Community Language Learning, the Silent Way, Suggestopedia, Whole Language, the Lexical Approach, and Competency-based Language Teaching appeared. Later, the Communicative approaches which include Communicative Language Teaching, the Natural Approach, Cooperative Language Learning, Content-based Instruction and Task-based Language Teaching emerged (Richard and Rodgers, 2001).

In fact, the Communicative Language Teaching (hereafter, CLT), aiming at both developing communicative competence in learners and considering all language skills as equally important, has the Content-based Instruction (hereafter, CBI) or Content-based language teaching (CBLT) as one of its spin-off approaches (Richard and Rodgers, 2001). So, the CBI has enjoyed much popularity and applicability since the early 1990s (Stoller, 2002).

However, in the Iranian context of teaching and learning English, CBI has received little attention in teaching English not only to English and non-English majors but in different levels of education ranging from primary schools, to secondary schools, and to university levels. Specifically speaking, the central bureau of Sama schools under the auspice of the Islamic Azad University in Iran has launched a new program for CBI at its primary and secondary school levels, but no nationwide program in the education ministry has been started by the government so far. As such, this study attempted to implement CBI in medical science courses at university level and compare it with the old grammartranslation method (hereafter, GTM) with regard to the students' course achievement and language learning orientation.

\section{REVIEW OF LITERATURE}

\section{A. Content-based Instruction}

CBI, as one of the spin-off approaches and process-based methodologies to CLT, has achieved much popularity and applicability since the early 1990s (Richard and Rodgers, 2001; Stoller, 2002), and different definitions with some degree of similarity have been posed for it. Brinton, Snow and Wesche (2003) defines it as "(...) the integration of 
particular content with language teaching aims (...)" or "the concurrent teaching of academic subject matter and second language skills". Leaver and Stryker (1989) claim that CBI is an instructional approach in which "language proficiency is achieved by shifting the focus of the course from the learning of language per se to the learning of subject matter". Further, Short (1993) holds that in CBI content topics, instead of grammar rules or vocabulary lists, are used by language teachers.

Moreover, CBI tries to develop both the students' language and their content knowledge through providing them with authentic, meaningful academic contexts. It also claims that the acquisition of language is most effective when the conditions of acquisition are analogous to those of first language acquisition (Krashen 1985; Savignon 1983; Snow 1993; Wesche 1993).

Basically, CBI has been presented in the two forms of language-driven approach and the content driven approach depending on the emphasis given to the language or content. In the former, the students' language development more than the content knowledge is emphasized, while in the latter, much emphasis is placed on assisting students acquire content learning by providing different kinds of linguistic and cognitive help (Met, 1998, cited in Butlor, 2005).

\section{B. CBI Models}

The models of CBI vary in design and implementation based on such factors as setting, level, and the nature of instruction. Some models are utilized in foreign language situations while others are used in second language environments. Some models have proved successful at the elementary school level whereas some have demonstrated their effectiveness at secondary or post-secondary levels. And finally, some models emphasize the content but in some models more emphasis is put on language (Duenas, 2004).

However, in line with the purposes of the study, three general models of CBI, namely, theme-based language instruction, sheltered content instruction, and adjunct language instruction will be introduced.

Theme-based language instruction (the concern of this study): In this model, which is also called theme-based or content-infused language instruction, the course is taught by a language instructor and "is structured around topics or themes, with the topics forming the backbone of the course curriculum" (Brinton, Snow and Wesche, 2003, p. 14).

Sheltered content instruction: Through this model, the instruction is implemented by a content expert who is a native speaker of the target language. In other words, it is defined as "content courses taught in the second language to a segregated group of learners by a content area expert, such as a university professor who is a native speaker of the target language" (Brinton, Snow and Wesche, 2003, p. 15).

Adjunct language instruction: Applying this model, students take part in two linked courses, a content course and a language course both of which include the same content in common and complement each other regarding jointly coordinated homework (Richard and Rodgers, 2001, p. 216).

Having presented some aspects of CBI, it seems warranted here to have a close look at the other method of teaching English employed in this study, i.e., the Grammar Translation.

\section{Grammar Translation Method}

The Grammar Translation method (hereafter, GTM) was the offspring of German scholarship, whose purpose is "to know everything about something other than the thing itself" (Rouse, 1925, cited in Kelly, 1969, p. 53). This method in fact was first known in the United States and dominated the teaching of foreign and European languages from the 1840s to the 1940s. The GTM is mostly based on the following principles (Richard and Rodgers, 2001, pp. 5-6):

1) The aim of studying a foreign language is to learn a language so as to read its literature for the advantage from the mental discipline and intellectual development which emanate from studying a foreign language, 2) reading and writing other than listening and speaking are more emphasized, 3) the sentence is the main focus for language practice and learning, 4) lots of emphasis is put on accuracy, 5) the deductive teaching of grammar is followed, and 6) the medium of instruction is the students' native language.

Many studies, conducted regarding the CBI, have concentrated on its impact in disciplines like accounting (Chau Ngan, 2011; Malmir, Najafi Sarem, \& Ghasemi, 2011), technology (Gaynor, 2013), Spanish (Pessoa, Henry, Donta, Tucker, \& Lee, 2007), Chinese Language Flagship program, and some other ESP courses. Also, some studies have utilized CBI at the elementary or secondary school levels (Omoto and Nyongesa, 2013; Ruby Yang, 2009). In addition, Stoller (2002) stated that teaching through CBI boosts learner's critical thinking and leads to their learning the language fast and with more pleasure. Moreover, the results of the Multicultural Improvement of Cognitive Abilities (MICA) project reveal that the students taught through CBI improved both in cognitive and academic achievements and in their language proficiency (Kessler and Quinn, 1987). However, few studies, if any, have been carried out to compare the effect of teaching English through the CBI and the GTM in the fields related to the medical sciences at university level. Thus, this study is an attempt to compare two essentially different methods of teaching, the Content-based Instruction and the Grammar-translation Method in students majoring in different fields of medical sciences with regard to their final course achievement and language learning orientation skills. As such, the following questions were presented:

Q1. Is there any significant difference between the students' achievement when taught through Content-based Instruction vs Grammar-Translation Method?

Q2. Is there any significant difference between the students' Language Learning Orientation (LLO) with respect to the method of language instruction (CBI vs GTM)? 


\section{METHODOLOGY}

\section{A. Subjects}

The subjects consisted of 82 freshmen majoring in the fields of Environmental Health $(\mathrm{N}=21)$, Laboratory Sciences $(\mathrm{N}=21)$, Anesthesia $(\mathrm{N}=19)$, and Public Health $(\mathrm{N}=21)$ at Gonabad university of medical sciences, Gonabad, Iran. They had previously a three-year experience of learning English at junior high schools and a four-year experience at high school and pre-requisite English Centers in the formal system of education in Iran. They were, also, of both genders (but mostly females) aged between 18-20 years old and were randomly assigned into two groups, so that the students in Environmental Health and Anesthesia courses were put into the grammar translation group and those in the Public Health and the Laboratory Sciences courses were placed in the content-based instruction group. They were in their second term of a B.Sc. degree at university taking a three-credit general English course, too. Table 1 shows the subject distribution into groups.

TABLE 1

THE DISTRIBUTION OF SUBJECTS INTO GROUPS

\begin{tabular}{|l|l|l|l|}
\hline Method & Course & N & Total \\
\hline Grammar Translation Method (GTM) & Environmental Health & 21 & \multirow{2}{*}{40} \\
\cline { 2 - 3 } Method 1 & Anesthesia & 19 & \\
\hline $\begin{array}{l}\text { Content-Based Instruction (CBI) } \\
\text { Method 2 }\end{array}$ & Laboratory Sciences & 21 & \multirow{2}{*}{42} \\
\cline { 2 - 3 } & Public Health & 21 & \\
\hline Total & & 82 \\
\hline
\end{tabular}

\section{B. Instrumentation}

Three instruments were utilized to collect data: 1) the Nelson test of achievement (hereafter, Nelson), form $050 \mathrm{C}, 2$ ) Noel's Language Learning Orientation Scale (hereafter, LLOS) questionnaire, and 3) a final achievement test (hereafter, FAT), a description of which follows:

\section{The Nelson Test of Achievement}

The Nelson test of achievement form $050 \mathrm{C}$ consists of 50 multiple-choice items measuring the learners' general language proficiency in English. The test has been developed by Fowler and Coe (1976) and its reliability and validity have been established. It was administered to examine whether the subjects were homogeneous in terms of their English language proficiency (See Appendix A).

\section{The Language Learning Orientation Scale questionnaire}

The Persian version of Language Learning Orientation Scale questionnaire which aims at exploring the learners' motivation orientation included 21 items. The 21 items in the questionnaire have been further divided into three subscales, namely, amotivation, external motivation, and internal motivation. Items 1 to 3 falls into the amotivation subscale which refers to a situation in which an individual does not see any relation between their action and the consequences of those actions yet he or she sees the consequences as arising from factors beyond his or her control (Deci and Ryan, 1985).

The external motivation including items 4 to 12 consists of the three other subscales each with three items. The external motivation indicates the actions performed to obtain some instrumental goals such as achieving a reward or avoiding a punishment. These subscales were termed as external regulation, introjected regulation, and identified regulation.

The internal motivation consisting items 13 to 21 encompasses three other subscales each with three items. The internal motivation, according to Deci and Ryan (1985), refers to motivation to carry out an activity merely for the purpose of satisfaction and pleasure that the action possesses. These subscales are referred to as knowledge, accomplishment, and stimulation.

The reliability of the subscales of this questionnaire has been reported by Khodadady and Khajavy (2013) as 0.84 for the Amotivation, 0.69 for External Regulation, 0.68 for Introjected Regulation, 0.76 for Identified Regulation, 0.73 for Accomplishment, 0.73 for Knowledge, and 0.75 for Stimulation.

\section{The Final Achievement Test}

The final achievement test taken from a test bank developed by the researcher included four sections of vocabulary, grammar, translation, and reading comprehension. The vocabulary section consisted of 8 items of word meaning, 8 items of word definition matching, and 10 items of fill-in-the blank type. The grammar section had one item of sentence combining form (The small number of grammar items is because less emphasis is given to grammar throughout the adopted textbook and vocabulary reading and reading comprehension of utmost importance). The translation section included four sentences to be translated into Persian. And the reading comprehension consisted of two passages with true/false, multiple-choice, and essay type items.

\section{The Textbook}

The main textbook employed was a general English textbook entitled "English for the Students of Medicine (I) written by Deedari, R. \& S. M. Zia Hosseini in 1989. This book contains 19 lessons, 9 of which were taught in this study due to both the length of each lesson and the time limitation. The focus of the book is mainly on vocabulary 
learning, reading comprehension and translation into the students' mother tongue (here, Persian). Each lesson is consisted of the following parts, sections, and subsections: Part I. Pre-reading (A. Pronunciation Practice, B. Word Study: Definitions, C. Word study: Definitions and Exemplifications, and D. Grammatical Points to Be Explained); Part II. Reading Passage (A. True and False Questions, B. Multiple-choice Items, and C. Oral Questions); Part III. Homework (Section One: vocabulary exercises, A and B parts of fill-in-the-blank type, and C. Synonym of matchingtype items; Section Two: open-ended exercises for the grammar points in two sub-parts; Section Three: Reading comprehension including one passage with multiple-choice questions; and Section Four: A. Translation practice consisting of a passage, and B. Some specialized terms to be translated into Persian.

\section{Procedure}

To conduct the study, several steps were taken. At first, the subjects $(\mathrm{N}=82)$ were chosen based on the convenience sampling method and were randomly assigned into two groups to be taught through either grammar translation method (method 1) or content-based instruction method (method 2).

Secondly, the Nelson test and the LLOS questionnaire (as a pre-test) were administered in the first session of class. The Nelson test took about 50 minutes and the LLOS questionnaire required about 8 minutes to be answered. The LLOS was in Persian, so the subjects had no questions (See Appendix B), and the Nelson test was in English; however, the researcher himself was available for any question.

Thirdly, the treatment was performed for one semester consisting of 25 one-hour-and-a-half sessions for a threecredit general English course using the general English textbook whose description was given above. In the CBI method, the subjects were divided into groups of four or three, the instruction was carried out both in English and Persian with more emphasis on English, group work was encouraged, the students worked cooperatively, the teacher was guiding, facilitating and directing the teaching and learning process where and when necessary. The teacher, besides, assessed performance frequently, geared the activities to the students' developmental and proficiency levels, needs, styles, and interests, attended to both form and function, established meaningful and clear situations for teaching and learning, made great use of realia and visual aids, involved all the students in class activities, created learner-centered activities, and attended to the students' problems with regard to meaning, pronunciation, and translation individually. As for the $\mathrm{CBI}$, the teaching procedure had the following characteristics: most often the language of instruction was Persian. Regarding the vocabulary, all the words were translated into Persian by the students and with the teacher's help, the students had to memorize list of words, fill in the blanks with the appropriate form of the words given, and do some matching exercises. With regard to the reading comprehension, the students read and translated a passage into Persian with the teacher's correcting their mispronunciation, misinterpretation or mistranslation, nearly all the questions and answers were in Persian, and the students were required to answer different types of questions like true/false, multiplechoice, or essay-type ones. In case of grammar, it was taught deductively. Afterwards, the students had to do the exercises.

Fourthly, at the end of the term, the FAT was administered along with the LLOS questionnaire (as the post-test). And finally, the obtained data were analyzed.

\section{E. Data Analysis}

To analyze the data, they were put into Statistical Package for Social Sciences (SPSS) software version 19 employing t-test and some correlational analyses. The t-test was run to ensure the homogeneity of the groups and to consider any significance difference in the subjects' performance regarding the Nelson test, LLOS questionnaire, and the FAT. Some correlation analyses were, also, performed between Nelson test, the subscales of LLOS questionnaire, and the FAT. The $\mathrm{P}$ value was set at 0.05 level of significance for all the analyses.

\section{RESULTS}

\section{A. Test of Normality}

In order to make sure that the two groups were initially homogenous, three tests of normality were run for the Nelson test, the Persian version of Noel's LLOS questionnaire, and the FAT. The obtained results indicated that all the three instruments were normal using Kolmogorov-Smirnov at 0.05 level of significance. The results appear in the tables 2 through 4 .

TABLE 2.

TEST OF NORMALITY FOR THE NELSON TEST

\begin{tabular}{|ll|l|l|l|}
\hline \multirow{4}{*}{ Method } & \multicolumn{3}{|l|}{ Kolmogorov-Smirnov $^{\mathrm{a}}$} \\
\cline { 3 - 5 } Nelson & Statistic & Df & Sig. \\
& GTM & 079 & 42 & $.200^{*}$ \\
& CBI & 139 & 40 & .051 \\
\hline \multicolumn{4}{|c|}{$\mathrm{P}>0.05$}
\end{tabular}


TABLE 3.

TEST OF NORMALITY FOR THE FINAL ACHIEVEMENT TEST (FAT)

\begin{tabular}{|c|c|c|c|c|}
\hline & \multirow[b]{2}{*}{ Method } & \multicolumn{3}{|c|}{ Kolmogorov-Smirnov $^{\mathrm{a}}$} \\
\hline & & Statistic & df & Sig. \\
\hline FAT & $\begin{array}{l}\text { GTM } \\
\text { CBI }\end{array}$ & $\begin{array}{l}.124 \\
.087\end{array}$ & $\begin{array}{l}42 \\
40\end{array}$ & $\begin{array}{l}.102 \\
.200^{*}\end{array}$ \\
\hline
\end{tabular}

TABLE 4.

TEST OF NORMALITY FOR NOEL'S LANGUAGE LEARNING ORIENTATION SCALE (LLOS)

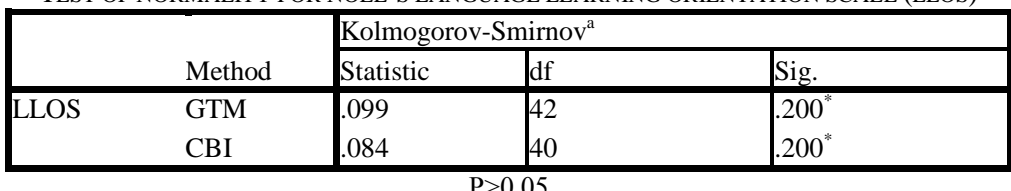

\section{B. T-test}

As mentioned earlier, several t-tests were performed in data analysis. First, a t-test was run for the Nelson test to ensure that the groups were homogeneous in terms of their English language proficiency. The results revealed that there was no significant difference between the groups in this regard at the onset of the study $(\mathrm{p}=0.98>0.05)$. Table 5 shows the results.

TABLE 5.

INDEPENDENT SAMPLE T-TEST/NELSON

\begin{tabular}{|ll|l|l|l|l|}
\hline \multirow{3}{*}{ Nelson } & Method & N & Mean & Std. Deviation & P Value \\
& GTM & 42 & 24.8810 & 6.29054 & 0.981 \\
& CBI & 40 & 24.8500 & 5.27476 & \\
\hline
\end{tabular}

Second, to make sure of the subjects' homogeneity in terms of their motivational orientation, a t-test was also performed for the LLOS questionnaire between the two methods. The obtained results (Table 6 below) indicated that there was not any significant difference between the methods in this regard, $(p=0.915)$.

TABLE 6.

INDEPENDENT SAMPLES T-TEST FOR LLOS QUESTIONNAIRE

\begin{tabular}{|ll|l|l|l|l|}
\hline \multicolumn{2}{|c|}{ Method } & $\mathrm{N}$ & Mean & Std. Deviation & P Value \\
\hline LLOS & GTM & 42 & 107.3810 & 15.34633 & 0.915 \\
& CBI & 40 & 107.0250 & 14.66111 & \\
\hline
\end{tabular}

Third, to investigate whether the types of instruction (CBI vs GTM) was effective, the students' score on the FAT was compared in the two groups using t-test, the result of which pointed out that the groups were significantly different from one other, $(\mathrm{p}<0.05$ and $\mathrm{p}=0.006$ for the CBI and GTM groups, respectively). Table 7 demonstrates the results.

TABLE 7.

INDEPENDENT SAMPLE T-TEST FOR GTM VS CBI

\begin{tabular}{|c|c|c|c|c|c|}
\hline & Method & $\mathrm{N}$ & Mean & Std. Deviation & P Value \\
\hline FAT & $\begin{array}{l}\text { GTM } \\
\text { CBI }\end{array}$ & $\begin{array}{l}42 \\
40\end{array}$ & $\begin{array}{l}14.8512 \\
16.1998\end{array}$ & $\begin{array}{l}2.36273 \\
1.94600\end{array}$ & 0.006 \\
\hline
\end{tabular}

Fourth, another t-test was run to examine the effect of gender in the FAT. The result showed that there was no significant difference between males $(\mathrm{M})$ and females $(\mathrm{F})$ though the females obtained a higher mean in the FAT (F mean=15.02 \pm 2.46 , and $\mathrm{M}$ mean=14.12 $\pm 1.84, \mathrm{p}=0.34)$. Table 8 delineates the results.

TABLE 8.

INDEPENDENT SAMPLES T-TEST FOR THE DIFFERENCE BETWEEN THE TWO GENDERS IN GTM GROUP

\begin{tabular}{|c|c|c|c|c|c|}
\hline & Gender & $\mathrm{N}$ & Mean & Std. Deviation & P Value \\
\hline GTM & $\begin{array}{l}\text { Male } \\
\text { Female }\end{array}$ & $\begin{array}{l}8 \\
34\end{array}$ & $\begin{array}{l}14.1250 \\
15.0221\end{array}$ & $\begin{array}{l}1.84197 \\
2.46134\end{array}$ & 0.34 \\
\hline
\end{tabular}

Fifth, another t-test was run to examine the effect of gender in the CBI group. The result showed that there was a significant difference between females and males ( $\mathrm{F}$ mean=16.60 \pm 1.91 , and $\mathrm{M}$ mean=14.97 \pm 1.53 , $\mathrm{p}=0.019$ ). Table 9 points out the results. 
TABLE 9.

INDEPENDENT SAMPLES T-TEST FOR THE DIFFERENCE BETWEEN THE TWO GENDERS IN CBI GROUP

\begin{tabular}{|c|c|c|c|c|c|}
\hline & Gender & $\mathrm{N}$ & Mean & Std. Deviation & P Value \\
\hline$\overline{\mathrm{CBI}}$ & $\begin{array}{l}\text { Male } \\
\text { Female }\end{array}$ & $\begin{array}{l}10 \\
30\end{array}$ & $\begin{array}{l}14.9740 \\
16.6083\end{array}$ & $\begin{array}{l}1.53915 \\
1.91487\end{array}$ & 0.019 \\
\hline
\end{tabular}

And finally, a paired t-test was performed to investigate whether the students' orientation in language learning has changed after the treatment. The obtained results appearing in Tables 10, 11, and 12 pointed out that there was a significant difference between the students' orientation and motivation towards learning English due to the intervention (In the tables below, PRELLOS stands for the LLOS before treatment and POSTLLOS shows its administration after treatment).

TABLE 10.

THE PAIRED SAMPLES T-TEST FOR THE LLOS BEFORE AND AFTER INTERVENTION FOR METHOD 1 (GTM)

\begin{tabular}{|ll|l|l|l|l|}
\hline \multicolumn{2}{|c|}{} & Mean & $\mathrm{N}$ & Std. Deviation & $\mathrm{P}$ \\
\hline Pair 1 & PRELLOS & 100.0250 & 40 & 11.85054 & 0.570 \\
& POSTLLOS & 98.0250 & 40 & 18.95269 & \\
\hline
\end{tabular}

TABLE 11.

THE PAIRED SAMPLES T-TEST FOR THE LLOS BEFORE AND AFTER INTERVENTION FOR METHOD 2 (CBI)

\begin{tabular}{|ll|l|l|l|l|}
\hline \multicolumn{2}{|c|}{} & Mean & N & Std. Deviation & P \\
\hline Pair 1 & PRELLOS & 100.2857 & 42 & 13.67620 & 0.042 \\
& POSTLLOS & 106.1190 & 42 & 15.76690 & \\
\hline
\end{tabular}

TABLE 12.

INDEPENDENT SAMPLES TEST AFTER INTERVENTION

\begin{tabular}{|c|c|c|c|c|c|}
\hline & Method & $\mathrm{N}$ & Mean & Std. Deviation & $\mathrm{P}$ \\
\hline POSTLLOS & $\begin{array}{l}\text { GTM } \\
\text { CBI }\end{array}$ & $\begin{array}{l}40 \\
42\end{array}$ & $\begin{array}{l}98.0250 \\
106.1190\end{array}$ & $\begin{array}{l}18.95269 \\
15.76690\end{array}$ & 0.038 \\
\hline
\end{tabular}

\section{Correlation}

To investigate whether there is any go-togetherness between the students' scores in the tests taken, some correlational analyses were carried out among which the correlation between the Nelson test and the FAT was significant for the two groups even though it was of a low coefficient $(\mathrm{r}=0.357)$. The result is presented in the Table 13 below.

TABLE 13.

THE CORRELATION BETWEEN THE NELSON AND THE FAT

\begin{tabular}{|ll|l|l|}
\hline \multicolumn{2}{|c|}{ FAT } & FAT & Nelson \\
& Pearson Correlation & 1 & $.357^{* *}$ \\
& Sig. (2-tailed) & & .001 \\
& $\mathrm{~N}$ & 82 & 82 \\
\hline \multirow{2}{*}{ Nelson } & Pearson Correlation & $.357^{* *}$ & 1 \\
& Sig. (2-tailed) & .001 & \\
& $\mathrm{~N}$ & 82 & 82 \\
\hline \multicolumn{2}{|l|}{} \\
\end{tabular}

Further, the correlations between each subscale of the LLOS questionnaire and the subjects' performance on the FAT were performed. The results indicated very low correlation coefficients except for FAT and Nelson in the GTM group $(\mathrm{r}=.409)$. Table 14 shows the results.

TABLE 14.

CORRELATIONS BETWEEN FAT \& NELSON IN GTM GROUP

\begin{tabular}{|ll|l|l|}
\hline \multicolumn{4}{|l|}{ CORRELATIONS BETWEEN FAT \& NELSON IN GTM GROUP } \\
\hline FAT & FAT & Nelson \\
& Pearson Correlation & 1 & $409^{* * *}$ \\
& Sig. (2-tailed) & .007 \\
& $\mathrm{~N}$ & 42 \\
\hline Nelson & Pearson Correlation & $409^{* *}$ & 1 \\
& Sig. (2-tailed) & .007 & 42 \\
& $\mathrm{~N}$ & 42 & \\
& $* *$. Correlation is significant at the 0.01 level (2-tailed).
\end{tabular}

\section{DISCUSSION}


As already mentioned, the purpose of this study was to investigate if there was any difference between the two methods of teaching English with regard to the students' final achievement and their LLO. In this regard, the following research questions were put forward: 1) Is there any significant difference between the students' achievement when taught through Content-based Instruction and Grammar-translation Method? and 2) Is there any significant difference between the students' Language Learning Orientation (LLO) before and after treatment via Content-based Instruction and Grammar-translation Method?

Regarding the first question, the students' achievement in the FAT indicated that there was a significant difference between the CBI and the GTM. That is, the students taught through the CBI method outperformed their counterpart group which was taught via the GTM. This finding pointing out the effectiveness of CBI is in line with those of some foreign language educators, to name a few: Crandall (1993), Short (1997), Snow (1998), and Stoller (2004). They claimed that CBI enjoys some benefits like fostering academic growth while also developing language proficiency. The finding is, also, consistent with those of Curtain (1995) and Met (1991); they asserted that language acquisition increases through CBI and the learners achieve more when the emphasis is more on the meaningful and relevant content other than the form itself.

In case of the second research question, as the obtained results revealed that the students' LLO and motivation have changed to some extent in the CBI group, it can be inferred that the CBI has been more effective in comparison to the GTM, a finding which is in accordance with those of Brinton, Snow and Wesche (2003). They held the view that the students' motivation would increase and their learning would be effectively promoted if the lesson content were regarded as relevant to them. The reason might be due to the fact that the activities employed were found to be more meaningful and interesting, and accordingly the students were more involved in the integrated and organized activities. Moreover, teaching through CBI led to the students' high motivation, great interest level, and more intrinsic motivation a finding which corresponds to what Grabe and Stoller (1997) and Boivin and Razali (2013) claimed. In addition, the finding is in line with those of Genesee (1998) and Met (1991) who believed that CBI is motivating since language is the means of providing meaningful and suitable content.

\section{CONCLUSION}

Through conducting this study, we, first, investigated to see if there was any significant difference between the students' achievement when taught through Content-based Instruction or Grammar-translation Method. Next, we explored the difference between the students' Language Learning Orientation before and after treatment via Contentbased Instruction and Grammar-translation Method.

As was mentioned above, it was discovered that the CBI group outperformed the GTM one. Thus, based on the findings, several conclusions can be drawn, and accordingly some implications can be put forward. At first, the CBI proved to be much more influential in light of the students' performance in the final achievement test. So, it is recommended that the CBI be more practiced and implemented in classes if EFL/ELT teachers want their students to be successful learners in terms of learning the foreign language and consequently regarding their performance in examinations.

Secondly, since there was a change in the students' orientation and attitude toward learning English using CBI, it can be concluded that group work, cooperative learning, student involvement, providing comprehensible input, and teaching at the right level are the things more needed and welcomed by the students; and the students could achieve better scores, as Chau Ngan (2011) states, in all aspects of ESP.

And finally, CBI, if adopted carefully and well-planned, can provide the students with comprehensible learning tasks and activities stimulating both problem solving and critical thinking, resulting in more achievement in linguistic and content areas, as well as higher language learning orientations.

However, it should be mentioned that the study had one limitation even though the researchers did their best to compensate for it. In fact, the main textbook employed for the CBI and GTM groups was the same. To make up the shortcoming, the researchers tried to adopt some other materials to be used in the CBI group. The research reports, magazine articles, and even some news related to the theme of each lesson were introduced to the students only in the CBI group and they were required to provide a summary or a discussion on them for the following sessions.

\section{APPendiX A. The Nelson Test OF ACHIEVEMENT (TEST 050 C)}

Directions: Choose the correct answer and mark your answer sheet. Only one answer is correct.
1. A) The bird are in the sky
C) The birds in a sky
B) A bird's in a sky
D) The bird's in the sky

2. What doing?
A) are they
B) do they
C) does they
D) is they

3. Jane and Tom ............... the door.
A) are walking at
B) walk at
$\begin{array}{ll}\text { C) walks to } & \text { D) are walking to }\end{array}$

4. Charles and I
A) am here
B) we are here
C) are here
D) we here 
5. Ann, what
A) is doing
B) she's doing
C) are doing
D) are you doing

..?

6. Tom's

A) in the

B) at the

C) into the

D) under

7. How many girls are there in the room?
A) There are any
B) There's one
C) A girl
D) There two

8. Mary works, but

B) does Tom?

C) Tom does?

D) Tom works?

9. $\mathrm{Liz}$ is looking at
A) them
B) they
C) there
D) their

10. Who's that girl?
A) He's Elizabeth
B) Her name Sarah
C) She's a good girl
D) It's Anne

11. Where's the dog?
A) He's under chair
B) There's on the table
C) It's near the window
D) Its here

12. Is John tall?
A) Yes, he's
B) No, he'sn't
C) No, his not
D) Yes, he is

13. What's his name?
A) It John
B) It's John
C) John it's the name
D) Its John

14. Do you draw or write?
A) I'm draw and write
C) I'm not draw but I'm write
B) I drawing and writing
D) I draw and I write

15. Is that a chair?
A) Yes, that's
B) Yes, there is
C) Yes, it is
D) Yes, it's that chair

16. Is this chair brown?
A) No, isn't brown chair
C) Yes, it's brown
B) No, this is the green chair
D) Yes, it is a brown

17. What's her father doing?
A) Her working in the garden
B) Working in the garden
C) Is working in the garden
D) She is working in the garden

18. How many books are there?
A) They're many
C) There are eight
B) There are many
D) Are two books there
B) Is that book a big red?
D) Is that red book big?
A) Is that red book a big?
C) Is red that big book?

20. Anne tomorrow
A) can sing
B) can to sing
C) is going sing
D) going to sing

21. The pen is his pocket.
A) in
B) into

22. The car is ... the tree.
A) near of
B) with
C) beside
D) next

C) at

D) to

23. What's that man?
A) He's John
B) Yes, it's a man
C) It's John
D) He's a teacher

24. Do you like the boat?
A) No, I don't like it
B) Yes, I like him

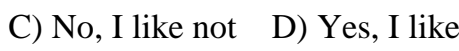

25. A) Ken is talking to Jane and we

C) Jane and we talking to Ken

B) We and Jane is talking to Ken

26. A) Is you friend that pretty girl?

C) Is that girl pretty your friend?

D) We are talking to Ken and Jane

B) Is that friend you're pretty girl?

D) Is that pretty girl your friend?

27. A) Is this your hat there?

C) Are those your hats there?

B) Are those your hat there?

D) Is this your hats here?

28. She is writing
A) on any book
B) in a paper
C) with a pen
D) by pencil

29. A) Do Gary live in Bristol now?

C) Is living in Bristol now, Gary?

B) Does Gary live in Bristol now?

30. Monday is the first day.
A) Tuesday is the second
B) The second is Thursday
C) Tuesday is the fourth
D) The fourth is Thursday

31. Mike is beside Pat. Pat is Mike.
A) behind
B) between
C) beside
D) in front of

32. Tom is Mrs Black's son. 

A) She is his daughter
B) He is his son
C) She is her son
D) $\mathrm{He}$ is her son

33. A) Go over there to they

B) Go over there to them

C) Come over there to me

D) Come to them over here

34. A) Look my garden, Susan!

B) Susan looks my garden.

C) Susan is look at my garden.

D) Look at my garden, Susan!

35. A) You know not the old man

B) You know a old man

C) An old man knows you

D) An old man don't knows you

36. Watch
A) him and his dog
B) he and he's dog

C) him and he's dog

D) him and its dog

37. Whose house is this? It's house.
A) the Mr Smith's
B) our
C) Mrs' Smith
D) she's

38. A) Where are they going put the books?

C) Where are they going to put the books?

B) Where there are going to put the books?

9. A) Jack's English and Anne are two

D) Where are there going put the books?

C) Jack's English and Anne's, too

B) Jack's English and Anne is too English

D) Jack's English and Anne is, too

40. Do pigs fly?
A) No, dogs don't
B) No, and not dogs, too
C) No, and dogs not
D) No, and dog doesn't fly

41. Jack is standing beside
A) us
B) its
C) they
D) your

42. This car is
A) of John
B) to John
C) John's
D) Johns'

43. A) Betty has some flower

C) Betty's any flowers

B) Betty's has any flowers

D) Betty has some flowers

44. A) These are the third lesson

C) This a lesson, too

B) This is the lesson two

D) This is the third lesson

45. A) Tom cans have Joan's bicycle

B) Tom can have Joan's bicycle

C) Tom can to have Joan's bicycle

D) Tom can has Joan's bicycle

46. It's 11:30.
A) Yes, it's thirty past eleven
B) Yes, it's half past eleven
C) Yes, its' thirty to twelve
D) Yes, its half to twelve
A) four hundred and thirty nine
C) four hundred thirty nine
B) four hundreds and thirty nine
D) four hundreds thirty and nine
48. A) The teacher don't like some book
B) The teacher doesn't likes some book
C) The teacher don't like his book
D) The teacher doesn't like her book

47. 439 is

49. Mother washes the girls' hair. Look, she
A) is washing it now
B) washes it now
C) is washing them now
D) washes them now

50. The cat has
A) the long legs
B) long legs
C) the legs long
D) legs long

APPENDIX B. The PERSIAN VERSION OF LANGUAGE LEARNing ORIENTATION SCALE

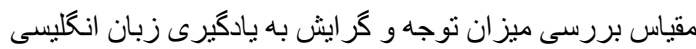

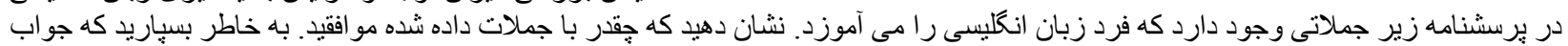

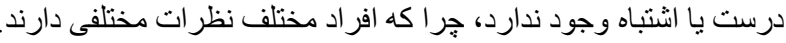




\begin{tabular}{|c|c|c|c|c|c|c|c|}
\hline 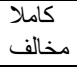 & 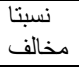 & 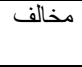 & 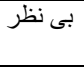 & 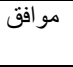 & 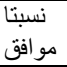 & مو افق املا & 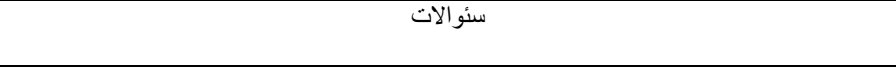 \\
\hline & & & & & & & 1-نميتو انم بفهمح كه جِر ا زبان انكليسى را ياد مى كيرم، و صر احتا بكُويم، اصلا اهميت نمى دهم. \\
\hline & & & & & & & 2-صادقانه بكويم، نمبدانم، و اقعا احساس مى كنم كه وقتم را با يادكيرى زبان انكليسى تلف ميكنم. \\
\hline & & & & & & & 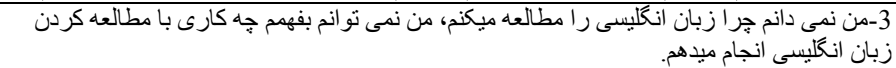 \\
\hline & & & & & & & 4-من زبان انكليسى را فرا ميكيرم تا در آينده شغل بهتر و با اعتبارترى داشته باشم. \\
\hline & & & & & & & 5-من زبان انكليسى را فرا ميكيرم نا در آينده حقوق بيشترى دريافت كنم. \\
\hline & & & & & & & 6-من زبان انكليسى را فر ا ميكيرم، جر ا كه احساس مى كنم ديكران اين انتظار را از من دارند. \\
\hline & & & & & & & 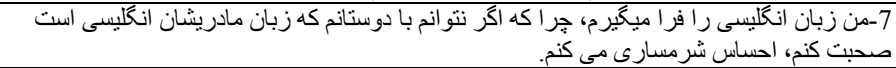 \\
\hline & & & & & & & 8-من زبان انغليسى را فر ا ميخيرم، جون اكر زبان انكليسى را ندانم احساس گَناه مى كنم. \\
\hline & & & & & & & 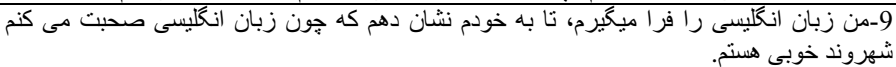 \\
\hline & & & & & & & را صح من زبان انكليسى را فرا ميكيرم، جر ا كه مى خو اهم فردى باشم كه مى تو اند بيش از يك زبان \\
\hline & & & & & & & 11-من زبان انكليسى را فرا ميكيرم، جُر ا كه فكر مى كنم براى رشد فردى ام خوب است. \\
\hline & & & & & & & صحبت كند. منان انكليسى را فرا ميكيرم، جر ا كه مى خو اهم فردى باشم كه مى تو اند به زبان دومى \\
\hline & & & & & & & 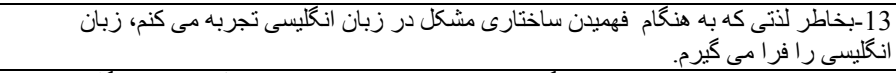 \\
\hline & & & & & & & 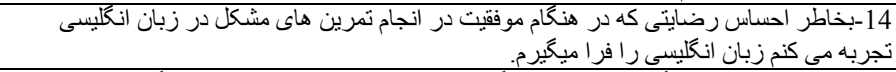 \\
\hline & & & & & & & 15-بخاطر لذنى كه به هنكام بيشرفت درياد كيرى زبان دوم تجربه مى كنم، زبان انكليسى را فرا \\
\hline & & & & & & & 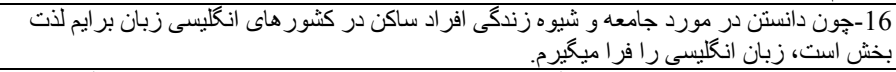 \\
\hline & & & & & & & فر ا ميخيرم. ربخر احساس رضايتى كه به هنكام كثف جيز هاى جديد به من دست مى دهد، زبان انكليسى را \\
\hline & & & & & & & 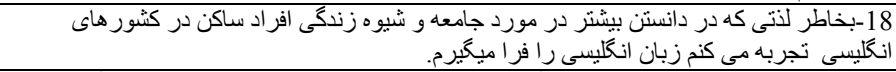 \\
\hline & & & & & & & فر ا ميخيرم. ربخر احساس لذت بخشى كه به هنگام شنيدن زبانهاى خارجى تجربه مى كنم زبان انكليسى را \\
\hline & & & & & & & انغليسى را ا فر ا ميخكيرم. لذت بخشى كه به هنگام صحبت كردن به زبان انكليسى تجربه مى كنم، زبان \\
\hline & & & & & & & 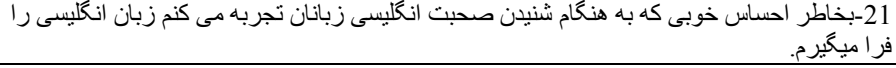 \\
\hline
\end{tabular}

\section{ACKNOWLEDGEMENT}

We are grateful to those students at Gonabad University of Medical Sciences, Gonabad, Iran, who patiently took the Nelson achievement test and the LLOS questionnaire.

\section{REFERENCES}

[1] Boivin, N. \& H. Razali. (2013). Content and language integration in the institute of teacher education - redesigning the EAP foundation programme. Malaysian Journal of ELT Research 9.2, 1-18.

[2] Brinton, D. M., M. A. Snow \& M. B. Wesche. (2003). Content-based second language instruction. Ann Arbor: The University of Michigan Press.

[3] Butler, Y. (2005). Content-based instruction in EFL contexts: Considerations for effective implementation. JALT Journal 27.2, 227-241.

[4] Chau Ngan, T. T. (2011). Content-based instruction in the teaching of English for accounting at Vietnamese college of finance and customs. English Language Teaching 4.3, 90-100.

[5] Crandall, J. A. (1993). Content-centered learning in the United States. Annual Review of Applied Linguistics 13, $111-126$.

[6] Curtain, H. (1995). Video entitled "Helena curtain: Integrating language and content instruction," available through the NFLRC second language teaching and curriculum center at the university of Hawai'i at Manoa.

[7] Deci, E. \& R. Ryan. (1985). Intrinsic motivation and self-determination in human behavior. New York: Plenum.

[8] Deedari, R \& S. M. Zia Hosseini. (1989). English for the students of medicine (I). Tehran: SAMT publication.

[9] Duenas, M. (2004). The whats, whys, hows and whos of content-based instruction in second foreign language education. International Journal of English Studies 4.1, 73-96.

[10] Fowler, W. S. \& N. Coe. (1976). Nelson English language tests. London: Bulter and Tannerltad.

[11] Gaynor, B. (2013). Content-based instruction in Muroran institute of technology: A critical evaluation. Muroran institute of technology academic resources archive 13, 157-167.

[12] Genesee, F. (1998). Content-based language instruction, (introduction to Chapter 5). In M. Met (eds.), Critical issues in early second language learning Reading MA: Scott Foresman-Addison Wesley, 103-105.

[13] Grabe, W., \& F. L. Stoller. (1997). Content-based instruction: Research foundations. In M. A. Snow \& D. M. Brinton (eds.), The content-based classroom: Perspectives on integrating language and content White Plains, NY: Longman, 5-21.

[14] Kelly, L. G. (1969). 25 Centuries of Language Teaching. New York: Newbury House. 
[15] Kessler, C. \& E. M. Quinn. (1987). SEL and science learning. ESL through content-area instruction: Mathematics, science, social studies SL and Science Learning. J. Crandall. Englewood Cliffd, NJ, Prentice-Hall Regents.

[16] Khodadady, E. \& G. H. Khajavay. (2013). Exploring the role of anxiety and motivation in foreign language achievement: A structural equation modeling approach. Porta Linguarum 20, 269-286.

[17] Krashen, S. D. (1985). The input hypothesis: Issues and implications. London: Longman

[18] Leaver, B. L. \& S. B. Stryker. (1989). Content-based instruction for foreign language classroom. Foreign Language Annals 22.3, 269-275.

[19] Malmir, A, S. Najafi Sarem, \& A. Ghasemi. (2011). The effect of task-based language teaching (TBLT) vs content-based language teaching (CBLT) on the Iranian intermediate ESP learners' reading comprehension. The Iranian EFL Journal 7.6, 7994.

[20] Met, M. (1991). Learning language through content: Learning content through language. Foreign Language Annals 24.4, 281295.

[21] Met, M. (1998). Curriculum decision-making in content-based language teaching. In J. Cenoz \& F. Genesee (eds.), Beyond bilingualism: Multilingualism and multilingual education, Philadelphia, PA: Multilingual Matters, 35-63.

[22] Omoto, M. P. \& W. J. Nyongesa. (2013). Content-based instruction: A study of methods of teaching and learning English in primary schools in Butula district. International Journal of Business and Social Science 4.5, 236-245.

[23] Pessoa, S., H. Henry, R. Donta, G. C Tucker \& H. Lee. (2007). Content-based instruction in the foreign language classroom: A discourse perspective. Foreign Language Annals 40.1, 102-121.

[24] Richard, J. C. \& T. S. Rodgers. (2001). Approaches and methods in language teaching (2nd ed). Cambridge: Cambridge University Press.

[25] Ruby Yang, C. C. (2009). Theme-based teaching in an English course for primary ESL students in Hong Kong. Electronic Journal of Foreign Language Teaching 6.2, 161-176.

[26] Savignon, S. (1983). Communicative competence: Theory and classroom practice. (2nd ed.) Reading, MA: Addison-Wesley.

[27] Short, D. J. (1993). Assessing integrated language and content instruction. TESOL Quarterly 27.4, 627-656.

[28] Short, D. (1997). Reading and writing and social studies: Research on integrated language and content in second language classrooms. In M. A. Snow \& D. M. Brinton (eds.), The content-based classroom: Perspectives on integrating language and content. New York: Addison-Wesley Longman, 213-232.

[29] Snow, M. A. (1993). Discipline-based foreign language teaching: Implications from EFL/ESL. In M. Kruger \& F. Ryan (eds.), Language and content: Discipline and content-based approaches to language study. Lexington, MA: DC Heath.

[30] Snow, M. A. (1998). Trends and issues in content-based instruction. Annual Review of Applied Linguistics 18, $243-267$.

[31] Stoller, F. (2002). Project work: A means to promote language and content. In J. C. Richards \& W. A. Renandya (eds.), Methodology in language teaching: An anthology of current practice. Cambridge: Cambridge University Press, 107-119.

[32] Stoller, F. (2004). Content-based instruction: Perspectives on curriculum planning. Annual Review of Applied Linguistics 24, 261-283.

[33] Wesche, M. (1993). Discipline-based approaches to language study: Research issues and outcomes. In M. Kruger \& F. Ryan (eds.), Language and content: Discipline and content-based approaches to language study. Lexington, MA: DC Heath.

Mostafa Amiri was born in Gonabad, Iran, in 1970. He graduated with a BA degree in Teaching English as a Foreign Language (TEFL) from Sistan and Baluchestan University, Zahedan, Iran, in 1992. He got his MA degree in TEFL from University for Teacher Education (UTE), Tehran, Iran, in 1995. Currently, he is a PhD candidate of TEFL at Ferdowsi University of Mashhad (the International Campus), Mashhad, Iran. His areas of interest are teaching and testing reading, teaching ESP courses, material development, and writing.

He is, also, a FACULTY MEMBER at the basic science department of Gonabad University of Medical Sciences, Gonabad, Iran, where he has taught pre-requisite, general English and ESP courses to students at different fields of medical sciences for more than 15 years. He has presented papers in some international conferences at home and abroad.

Mr Amiri is a member of Teaching English Language and Literature Society of Iran (TELLSI). He is, also, the English editor of the two quarterly journals of "Ofogh-e-Danesh" and "Health and Research" (JHR) affiliated to Gonabad University of Medical Sciences, Gonabad, Iran.

Azar Hosseini Fatemi was born in 1951 in Mashhad, Iran. She got her BA degree in English Language and Literature from Ferdowsi University of Mashhad, Mashhad, Iran. She received an MA degree in TEFL from New Mexico, State University, USA in 1980, and a PhD degree from Panjab University, India. Her field of interests is research, teaching and learning a second language, and sociolinguistics.

She is an ASSOCIATE PROFESSOR of TEFL at Ferdowsi University of Mashhad, Iran. She has about 29 years of teaching experience at university level. She has published several articles in different international journals in the area of applied linguistics.

Dr. Hosseini Fatemi is the executive manager and a member of editorial board of "Ferdowsi Review, An Iranian Journal of TESOL, Literature and Translation Studies". 